\title{
San-Huang-Xie-Xin-Tang Protects against Activated Microglia- and 6-OHDA-Induced Toxicity in Neuronal SH-SY5Y Cells
}

\author{
Yu-Tzu Shih, ${ }^{1}$ Ing-Jun Chen, ${ }^{2}$ Yang-Chang Wu, ${ }^{1}$ and Yi-Ching Lo ${ }^{2}$ \\ ${ }^{1}$ Graduate Institute of Natural Products, Kaohsiung Medical University, Kaohsiung 807, Taiwan \\ ${ }^{2}$ Department of Pharmacology, College of Medicine, Kaohsiung Medical University, Kaohsiung 807, Taiwan
}

Correspondence should be addressed to Yi-Ching Lo, yichlo@kmu.edu.tw

Received 21 July 2008; Accepted 3 March 2009

Copyright (C) $2011 \mathrm{Yu}$-Tzu Shih et al. This is an open access article distributed under the Creative Commons Attribution License, which permits unrestricted use, distribution, and reproduction in any medium, provided the original work is properly cited.

\begin{abstract}
San-Huang-Xie-Xin-Tang (SHXT), composed of Coptidis rhizoma, Scutellariae radix and Rhei rhizoma, is a traditional Chinese herbal medicine used to treat gastritis, gastric bleeding and peptic ulcers. This study investigated the neuroprotective effects of SHXT on microglia-mediated neurotoxicity using co-cultured lipopolysaccharide (LPS)-activated microglia-like BV-2 cells with neuroblastoma SH-SY5Y cells. Effects of SHXT on 6-hydroxydopamine (6-OHDA)-induced neurotoxicity were also examined in SH-SY5Y cells. Results indicated SHXT inhibited LPS-induced inflammation of BV-2 cells by downregulation of iNOS, NO, COX$2, \mathrm{PGE}_{2}, \mathrm{gp} 1^{\text {phox }}$, iROS, TNF- $\alpha$, IL- $1 \beta$, inhibition of $\mathrm{I} \kappa \mathrm{B} \alpha$ degradation and upregulation of HO- 1 . In addition, SHXT increased cell viability and down regulated nNOS, COX-2 and gp91 phox of SH-SY5Y cells co-cultured with LPS activated BV-2 cells. SHXT treatment increased cell viability and mitochondria membrane potential (MMP), decreased expression of nNOS, COX-2, gp91 phox and iROS, and inhibited I $\kappa$ B $\alpha$ degradation in 6-OHDA-treated SH-SY5Y cells. SHXT also attenuated LPS activated BV-2 cells- and 6-OHDA-induced cell death in differentiated SH-SY5Y cells with db-cAMP. Furthermore, SHXT-inhibited nuclear translocation of $\mathrm{p} 65$ subunit of NF- $\kappa$ B in LPS treated BV-2 cells and 6-OHDA treated SH-SY5Y cells. In conclusion, SHXT showed protection from activated microglia- and 6-OHDA-induced neurotoxicity by attenuating inflammation and oxidative stress.
\end{abstract}

\section{Introduction}

Inflammation appears to be a complicating factor in many age-related neurodegenerative diseases, such as Parkinson's disease (PD) [1], Alzheimer's disease (AD) [2] and multiple sclerosis [3]. Microglia are thought to mediate the innate defense system in the central nervous system [4]. Activated microglia enhances pro-inflammatory and neurotoxic responses and neuronal injury $[5,6]$. Microgliamediated neurotoxicity was induced through release of proinflammatory cytokines such as tumor-necrosis factor alpha (TNF)- $\alpha$, interleukin $1 \beta$ (IL-1 $\beta$ ), nitric oxide (NO) and prostaglandin $\mathrm{E}_{2}\left(\mathrm{PGE}_{2}\right)$, this yields enhanced reactive oxygen species (ROS) [7] and reactive nitric oxide species (RNS) $[8,9]$. The deleterious consequences of excessive oxidation and pathophysiological role of ROS have been intensively studied in Alzheimer's disease. Studies indicated that antiinflammatory or anti-oxidative stress drugs exert neuroprotective effects [10-13]. Therefore, anti-inflammatory agents and antioxidants are considered a promising approach to slowing the progression and limiting the extent of neuronal cell loss in these disorders.

Many herbal medicines and dietary supplements are sold as aids to improve memory, treat neurodegenerative diseases or create favorable effects on the central nervous system. Increasing evidence has suggested that traditional Chinese medicines or herbal extracts possess neuroprotective benefits through their distinct and multiple mechanisms, including anti-inflammation and anti-oxidation [14-19]. San-HuangXie-Xin-Tang (SHXT), a traditional Chinese medicinal formula containing Coptidis rhizome (Coptis chinesis Franch), Scutellariae radix (Scutellaria baicalensis Georgi) and Rhei rhizome (Rheum officinale Baill), has been used to treat gastritis, gastric bleeding and peptic ulcers [20]. The preventive effects of SHXT on lipopolysaccharide (LPS) and Helicobacter pylori-induced inflammatory responses have been confirmed by our previous studies [21-23]. Studies indicate that several components in SHXT show inhibitory effects on 
neurotoxicity. Baicalein and baicalin, the major flavonoids in Scutellaria baicalensis, can reduce beta amyloid proteininduced neurotoxicity [24]. Baicalein $[14,18]$ and wogonin [19] attenuate inflammation-mediated neurodegeneration $[14,18,19]$. Baicalin attenuates oxygen-glucose deprivationinduced injury in neurons [25]. Emodin, an anthraquinone derivative extracted from Rhei rhizome, decreases glutamateinduced neurotoxicity [26].

LPS is commonly used to investigate the impact of inflammation on neuronal death, and studies indicate that microglia are necessary for LPS-induced neurotoxicity [27, 28]. LPS is not toxic to neurons, but LPS stimulates glial cells to produce factors that are toxic to neurons [28-30]. On the other hand, the auto-oxidation of the neurotransmitter dopamine to 6-hydroxydopamine (6-OHDA) generates ROS and reactive quinones subsequently inducing cell death [31, 32]. Therefore, we investigated the effects of SHXT on LPS activated microglia-induced neurotoxicity by using the in vitro model of co-culture microglia-like BV-2 cells with the neuronal-like neuroblastoma SH-SY5Y cell. We also examined the effects of SHXT on 6-OHDA-induced neurotoxicity in dopaminergic neuroblastoma SH-SY5Y cells.

\section{Materials and Methods}

2.1. Reagents. The voucher specimen and method for extraction and analysis of SHXT were described previously [22]. Briefly, a blended mixture of Coptidis rhizome, root of Scutellariae radix and rhizome of Rhei officinale Baill was prepared in a ratio of $1: 1: 2$, respectively. The content of each component in SHXT is shown as follows $(\mu \mathrm{g} / \mathrm{mL})$ : baicalin $1153.07 \pm 56.36$, baicalein $82.81 \pm 3.74$, emodin $11.15 \pm 1.22$, wogonin $19.55 \pm 0.83$, rhein $126.12 \pm 3.84$, berberine $62.14 \pm 4.27$, coptisine $6.15 \pm 0.34$, palmatine $25.11 \pm 3.78$, sennoside A $128.02 \pm 13.56$ and sennoside B $95.90 \pm 3.59$. Dimethyl sulfoxide (DMSO), lipopolysaccharide (LPS, L8274) from Escherichia coli (O26:B6), 3[4,5-dimethylthiazol-2-yl]-2,5-diphenyltetrazolium bromide (MTT), 2',7'-dichloro-dihydrofluorescein diacetate ( $\mathrm{H}_{2}$ DCF-DA), 6-hydroxydopamine (6-OHDA), dibutyryl cyclic AMP (db-cAMP), mouse antibody against iNOS and $\beta$-actin were purchased from Sigma Aldrich (USA). Dulbecco's modified Eagle's medium (DMEM), fetal bovine serum (FBS), penicillin, amphotericin B and streptomycin were purchased from GIBCO/BRL Life Technologies (USA). Mouse antibody against $\mathrm{gp} 91^{\text {phox }}$ and all materials for SDS-polyacrylamide gel electrophoresis were purchased from Bio-Rad (USA). Goat antibody against COX-2 and $\mathrm{HO}-1$, mouse antibody against $\mathrm{I} \kappa \mathrm{B} \alpha$, rabbit antibody against nNOS and all horseradish peroxidase-conjugated secondary antibodies were purchased from Santa Cruz Biotechnology (USA). Enhanced chemiluminescence agent was purchased from PerkinElmer Life and Analytical Sciences (USA). TNF- $\alpha$, IL- $1 \beta$ and PGE $_{2}$ enzyme immunoassay kits and NE-PER Nuclear and Cytoplasmic Extraction Reagents were purchased from Pierce Endogen (USA). TransFactor Family Colorimetric Kit NF- $\kappa$ B was purchased from BD Bioscience, Clontech (USA). All other chemicals were purchased from Sigma Chemical Company (USA).
2.2. Microglial BV-2 Cell Culture and Activated Microglia with LPS. Mouse microglial cell line BV-2 was cultured in DMEM containing $10 \%(\mathrm{v} / \mathrm{v})$ heat-inactivated FBS, $4 \mathrm{mM}$ glutamine, $100 \mathrm{U} / \mathrm{mL}$ penicillin, $100 \mathrm{mg} / \mathrm{mL}$ streptomycin and $0.25 \mathrm{mg} / \mathrm{mL}$ amphotericin $\mathrm{B}$ at $37^{\circ} \mathrm{C}$ in a humidified incubator under $5 \% \mathrm{CO}_{2}$ and $95 \%$ air. For the purpose of experiment, BV-2 cells were plated in 6-, 24- or 96-well sterile plates $\left(1 \times 10^{5}\right.$ cells $\left./ \mathrm{mL}\right)$. Then, cells were stimulated with LPS alone $(100 \mathrm{ng} / \mathrm{mL})$ or LPS with different concentrations of SHXT.

2.3. Human SH-SY5Y Neuroblastoma Cell Culture. The human neuroblastoma cell line SH-SY5Y (ATCC CRL-2266) was cultured in a medium consisting of a $1: 1$ mixture of DMEM and Ham's F-12 medium containing 10\% heatinactivated FBS, $4 \mathrm{mM}$ glutamine, $100 \mathrm{U} / \mathrm{mL}$ penicillin, $100 \mathrm{mg} / \mathrm{mL}$ streptomycin and $0.25 \mathrm{mg} / \mathrm{mL}$ amphotericin $\mathrm{B}$ at $37^{\circ} \mathrm{C}$ in a humidified incubator under $5 \% \quad \mathrm{CO}_{2}$ and $95 \%$ air. In order to investigate the neuroprotective effect of SHXT on differentiated neuronal cell, SH-SY5Y cells were treated with $1 \mathrm{mM}$ db-cAMP, a permeable analog of cAMP, to induce neuronal differentiation. SH-SY5Y cells $\left(1 \times 10^{5}\right.$ cells $\left./ \mathrm{mL}\right)$ were plated in 96 -well sterile plates and $\mathrm{db}$-cAMP was dissolved in distilled water and added to each well at a concentration of $1 \mathrm{mM}$ in DMEM containing $10 \%$ FBS. The cells were then incubated for 4 days at $37^{\circ} \mathrm{C}$, with the medium refreshed daily. Then, cells were treated with 6-OHDA alone $(100 \mu \mathrm{M})$ or 6-OHDA with different concentrations of SHXT for $24 \mathrm{~h}$.

2.4. Co-Culture of SH-SY5Y Cells with Microglial BV-2 Cells. The effects of SHXT on microglia-mediated and inflammation-associated neuronal damage were determined using LPS stimulated BV-2 cells as a model of activated microglia [11]. Non-differentiated or differentiated SH-SY5Y cells were plated in 6- or 24-well plates $\left(1 \times 10^{5}\right.$ cells $\left./ \mathrm{mL}\right)$ and BV-2 cells were seeded onto cell culture inserts (pore size of $0.2 \mu \mathrm{m}$; NUNCA/S, Roskilde, Denmark). Then the inserts were placed in the wells where SH-SY5Y cells were growing in DMEM containing 10\% (v/v) heat-inactivated FBS, $4 \mathrm{mM}$ glutamine, $100 \mathrm{U} / \mathrm{mL}$ penicillin, $100 \mathrm{mg} / \mathrm{mL}$ streptomycin and $0.25 \mathrm{mg} / \mathrm{mL}$ amphotericin $\mathrm{B}$ at $37^{\circ} \mathrm{C}$ in a humidified incubator under $5 \% \mathrm{CO}_{2}$ and $95 \%$ air. The BV-2 and SH-SY5Y co-cultured cells were separated by filters present in the insert. In co-culture conditions, BV-2 cells were then stimulated with LPS $(100 \mathrm{ng} / \mathrm{mL})$ or LPS + SHXT for $24 \mathrm{~h}$.

2.5. Cell Viability Assay. Cell viability was measured by a quantitative colorimetric assay with MTT, showing mitochondrial activity of living cells. In mono-culture, BV-2 or SH-SY5Y cells in 96-well plates were incubated with $25-200 \mu \mathrm{g} / \mathrm{mL}$ of SHXT for $24 \mathrm{~h}$. In 6-OHDA-induced neurotoxicity, non-differentiated or differentiated SH-SY5Y cells were treated with or without 6-OHDA $(100 \mu \mathrm{M})$ or 6$\mathrm{OHDA}+\mathrm{SHXT}$ for $24 \mathrm{~h}$. Under co-culture conditions, BV2 cells were treated with or without LPS $(100 \mathrm{ng} / \mathrm{mL})$ or LPS + SHXT for $24 \mathrm{~h}$. After incubation, inserts containing 
BV-2 cells were removed. Non-differentiated or differentiated SH-SY5Y cells were incubated with MTT at a final concentration of $0.5 \mathrm{mg} / \mathrm{mL}$ for $3 \mathrm{~h}$ at $37^{\circ} \mathrm{C}$. The reaction was terminated by addition of $200 \mu \mathrm{L}$ of DMSO. The amount of MTT formazon product was then determined by measuring the absorbance at $560 \mathrm{~nm}$ using a microplate reader.

2.6. Nitrite Measurement. Production of nitric oxide (NO) was determined by measuring the level of accumulated nitrite, a metabolite of $\mathrm{NO}$ in the culture supernatant using Griess reagent ( $1 \%$ sulfanilamide and $0.1 \% \mathrm{~N}$-(1naphthyl)ethylenediamide in $5 \%$ phosphoric acid). After $24 \mathrm{~h}$ of treatment with LPS $(100 \mathrm{ng} / \mathrm{mL})$ alone or LPS + SHXT, the culture supernatants were collected and mixed with an equal volume of Griess reagent and incubated at room temperature for $10 \mathrm{~min}$. The absorbance was measured at $540 \mathrm{~nm}\left(\mathrm{OD}_{540}\right)$.

2.7. Enzyme-Linked Immunosorbent Assay (ELISA). The productions of IL- $1 \beta, \mathrm{PGE}_{2}$ and TNF- $\alpha$ in supernatant were detected using ELISA kits from Endogen (USA) according to the manufacturer's instructions. IL- $1 \beta$ and $\mathrm{PGE}_{2}$ in the supernatant were determined after $24 \mathrm{~h}$ of LPS treatment. TNF- $\alpha$ was determined after $2 \mathrm{~h}$ of LPS treatment.

2.8. NF- $\kappa B$ DNA-Binding Activity. The DNA-binding activities of transcription factors in cells were determined by enzyme-linked DNA-protein interaction assay (ELDIA), according to a previously described method [21,33]. Nuclear protein extracts were prepared using NE-PER Nuclear and Cytoplasmic Extraction Reagent as described previously [34]. DNA-p65 NF- $\kappa$ B-binding activity was measured with a BD Mercury TransFactor kit (BD Bioscience, Clontech), which detects DNA binding by specific transcription factors, according to the manufacturer's instructions [35].

2.9. Western Blot Analysis. After treatment with indicated agents, cells were collected and lysed to determine expression of nNOS, iNOS, COX-2, gp91 phox, $\mathrm{I} \kappa \mathrm{B} \alpha$ and $\mathrm{HO}-1$. The lysates were centrifuged at $15000 \times \mathrm{g}$ for $30 \mathrm{~min}$ at $4^{\circ} \mathrm{C}$. The supernatant was then collected for SDS-polyacrylamide gel electrophoresis. Protein concentration was determined with the Bio-Rad protein assay kit following the manufacturer's guide. Cell membranes were obtained by ultracentrifugation of the supernatant at $26000 \times \mathrm{g}$ for $1 \mathrm{~h}$ at $4^{\circ} \mathrm{C}$. Equal amounts of protein $(20 \mu \mathrm{g}$ per lane) were separated on a $10 \%$ polyacrylamide gel and transferred to polyvinylidene difluoride membranes (PerkinElmer Life and Analytical Sciences). Non-specific binding was blocked with TBST ( $50 \mathrm{mM}$ Tris- $\mathrm{HCl}, \mathrm{pH}$ 7.6, $150 \mathrm{mM} \mathrm{NaCl}, 0.1 \%$ Tween 20 ) containing $5 \%$ non-fat milk for $1 \mathrm{~h}$ at room temperature. The membranes were then each incubated overnight at $4^{\circ} \mathrm{C}$ with one of the following specific primary antibodies: mouse antiiNOS $(1: 1000)$, mouse anti-gp91 ${ }^{\text {phox }}(1: 1000)$, mouse anti$\beta$-actin $(1: 20000)$, rabbit anti-nNOS $(1: 1000)$, mouse anti$\mathrm{I} \kappa \mathrm{B} \alpha(1: 500)$, rabbit anti-HO- $(1: 1000)$ and goat antiCOX-2 (1:5000). Membranes were washed six times for $5 \mathrm{~min}$ with TBST. The appropriate dilutions of secondary antibodies (diluted $1: 1000$ ) were incubated for $1 \mathrm{~h}$. After six washes with TBST, the protein bands were detected with the enhanced chemiluminescence reagent (PerkinElmer Life and Analytical Sciences).

2.10. Measurement of Intracellular Reactive Oxygen Species. The level of intracellular reactive oxygen species (ROS) was quantified by fluorescence with $\mathrm{H}_{2}$ DCF-DA. Following incubations with the indicated treatments, microglial BV-2 cells or neuronal SH-SY5Y cells were loaded with $10 \mu \mathrm{M}$ of $\mathrm{H}_{2} \mathrm{DCF}-\mathrm{DA}$ for $30 \mathrm{~min}$ at $37^{\circ} \mathrm{C}$. Cells were then washed three times with phosphate-buffer saline, $\mathrm{pH} 7.4$, and the relative levels of fluorescence were analyzed by a spectrophotofluorimeter (FLUOstar OPTIMA, BMG LABTECH, Germany, $495 \mathrm{~nm}$ excitation and $520 \mathrm{~nm}$ emission). Intracellular ROScontaining cells were identified as those with increased FITC fluorescence of oxidized $\mathrm{H}_{2}$ DCF.

2.11. Measurement of Mitochondrial Membrane Potential. Mitochondrial membrane potential was measured by the incorporation of a cationic fluorescent dye rhodamine 123 . The reduction in fluorescent intensity of rhodamine 123 staining represented a fall in the mitochondrial membrane potential. After $24 \mathrm{~h}$ of incubation in normal medium with or without treatment, the cells were changed to serumfree medium containing $10 \mu \mathrm{M}$ rhodamine 123 , there they were incubated for $15 \mathrm{~min}$ at $37^{\circ} \mathrm{C}$. The cells were then collected, and the fluorescence intensity was analyzed within $15 \mathrm{~min}$ by a spectrophotofluorimeter (FLUOstar OPTIMA, BMG LABTECH, Germany, $490 \mathrm{~nm}$ excitation and $515 \mathrm{~nm}$ emission).

2.12. Data Analysis. Data were expressed as mean \pm SEM. Analysis of variance (ANOVA) was used to assess the statistical significance of the differences followed by Tukey's test for all pair's comparisons. A value of $P<.05$ was considered statistically significant. The data were analyzed with the Statistical Package for Social Sciences (SPSS, Chicago, IL).

\section{Results}

3.1. Effects of SHXT on LPS-Activated Microglial BV-2 Celland 6-OHDA-Induced Loss of SH-SY5Y Cell Viability. Cells were incubated with or without SHXT for $24 \mathrm{~h}$. According to the results of MTT assay, SHXT $(25,50,100$ and $200 \mu \mathrm{g} / \mathrm{mL})$ did not effect the cell viability of BV-2 cells (Figure 1(a)) and SH-SY5Y cells (Figure 1(b)). In order to examine the effect of SHXT on LPS-activated microglia-mediated cell viability, co-culture of BV-2 cells with non-differentiated or differentiated SH-SY5Y cells was investigated. As shown in Figures 1(c) and 1(d), SHXT attenuated LPS (100 ng/mL)-activated BV-2 cells-induced cell death in non-differentiated and differentiated SH-SY5Y cells. Moreover, exposure of nondifferentiated (Figure 1(e)) and differentiated (Figure 1(f)) SH-SY5Y cells to 6-OHDA induced significant cell death. SHXT increased cell viability in 6-OHDA treated nondifferentiated (Figure 1(e)) and differentiated (Figure 1(f)) SH-SY5Y cells. SHXT protected against activated microgliaand 6-OHDA-induced differentiated neuronal cell death 


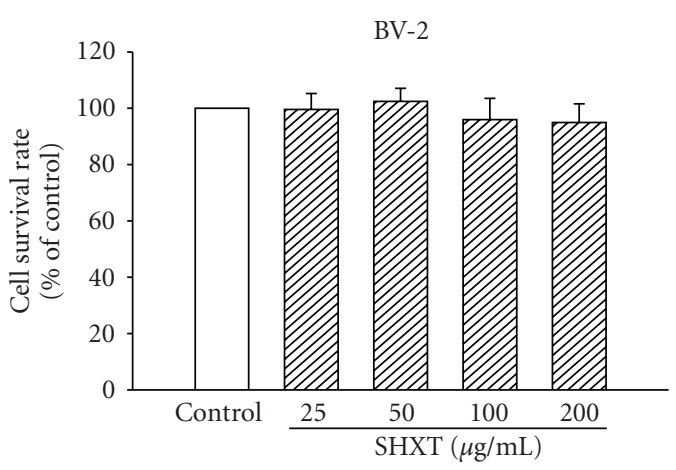

(a)

BV-2/SH-SY5Y

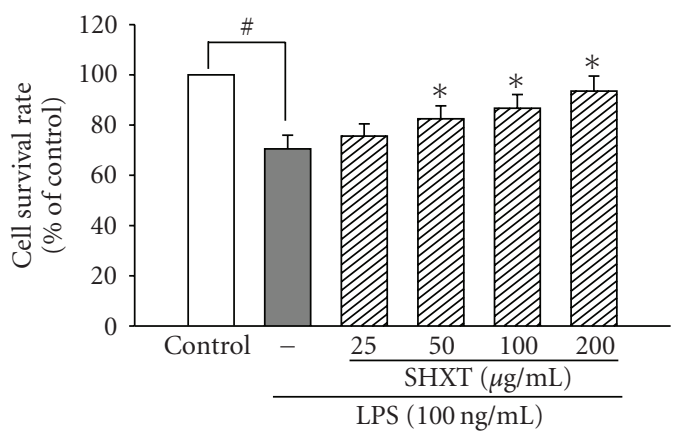

(c)

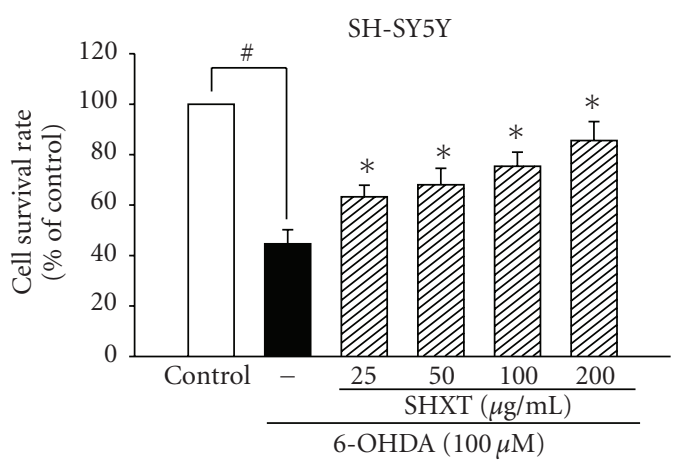

(e)

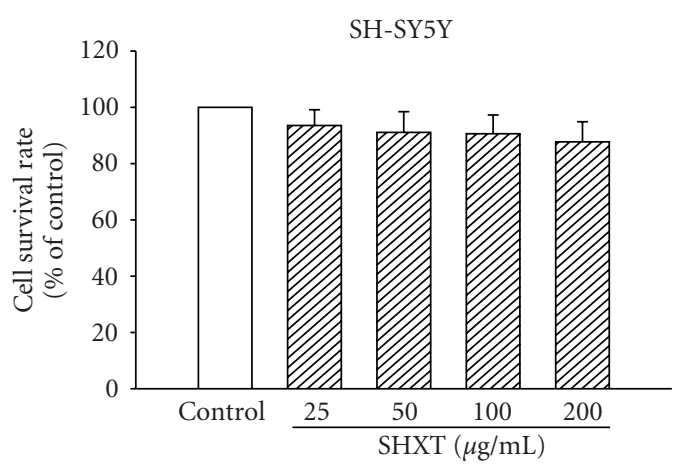

(b)

BV-2/differentiated SH-SY5Y

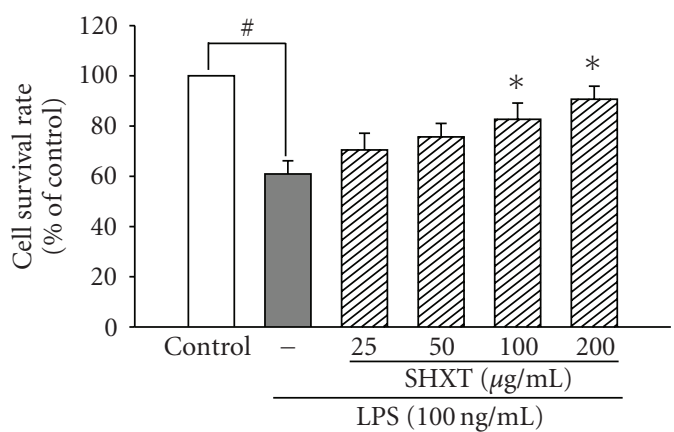

(d)

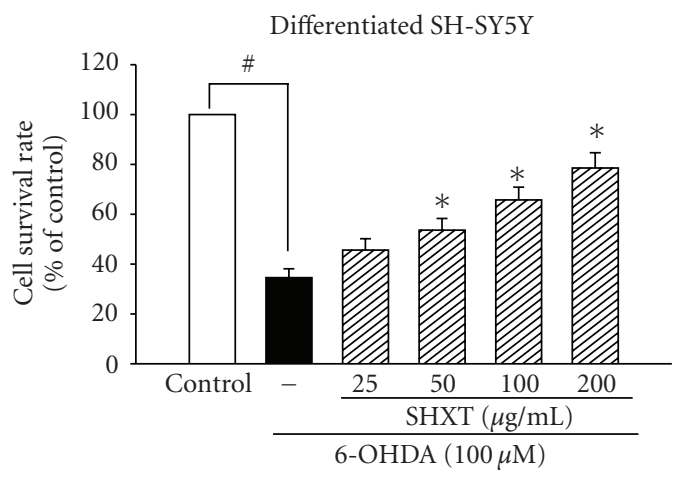

(f)

FIGURE 1: Effects of SHXT on microglial BV-2 cells (a), neuroblastoma SH-SY5Y cells (b), lipopolysaccharide (LPS, $100 \mathrm{ng} / \mathrm{mL})$ activated BV2 treated non-differentiated (c) and differentiated (d) SH-SY5Y cells, and 6-hydroxydopamine (6-OHDA, $100 \mu \mathrm{M})$ treated non-differentiated (e) and differentiated (f) SH-SY5Y cells. Cells were treated with SHXT (25-200 $\mu \mathrm{g} / \mathrm{mL}$ ) for $24 \mathrm{~h}$. Cell viability was determined by MTT assay. Bars represent the mean \pm SEM from six independent experiments. ${ }^{\#} P<.05$ versus control, ${ }^{*} P<.05$ versus LPS or 6 -OHDA only.

at the concentrations from 100 to $200 \mu \mathrm{g} / \mathrm{mL}$ and 50 to $200 \mu \mathrm{g} / \mathrm{mL}$, respectively. In addition, we examined dopamine receptor expression of differentiated SH-SY5Y cells using western blotting, and marked increase of dopamine receptor expression was observed (online Supplementary Figure S1).

3.2. LPS-Induced Inflammation and Associated Oxidative Stress-Related Factors in BV-2 Cells were Reduced by SHXT. To investigate whether SHXT inhibited LPS-activated microglia-induced inflammatory and oxidative stress factors, the effects of SHXT on the associated noxious factors of LPS-treated BV-2 cells were examined. As shown in Figure 2, LPS $(100 \mathrm{ng} / \mathrm{mL})$ increased expression of iNOS, COX-2 and gp91 phox in BV-2 cells, which were inhibited by SHXT treatment. Pairwise comparison at each concentration by Tukey's test indicated that SHXT concentrationdependently inhibited iNOS at a concentration of 50 and $200 \mu \mathrm{g} / \mathrm{mL}$ and inhibited COX-2 at a concentration of 25,50 , 100 and $200 \mu \mathrm{g} / \mathrm{mL}$. Additionally, SHXT upregulated HO1 expression in LPS treated BV-2 cells in a concentrationdependent manner from 25 to $200 \mu \mathrm{g} / \mathrm{mL}$ (Figure 2(d)). SHXT also reduced LPS-induced $\mathrm{NO}, \mathrm{PGE}_{2}$ and iROS 

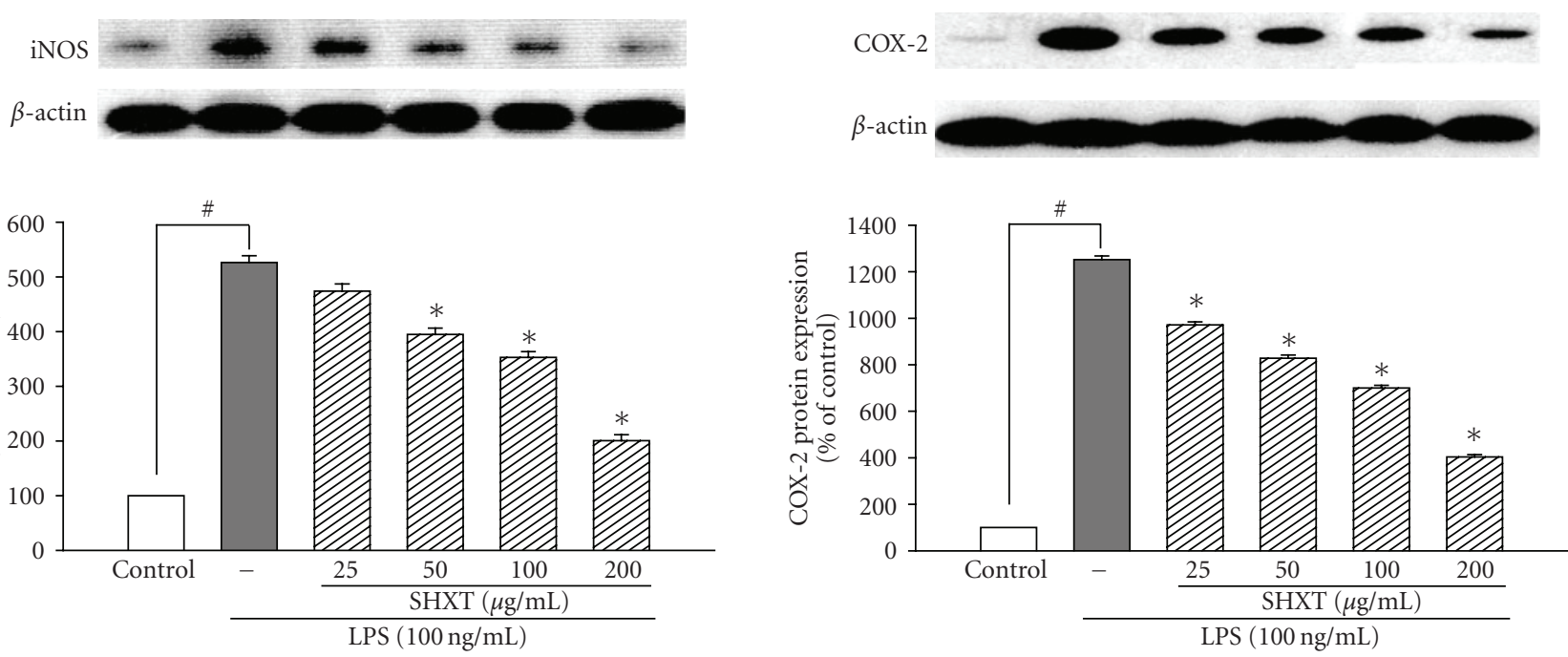

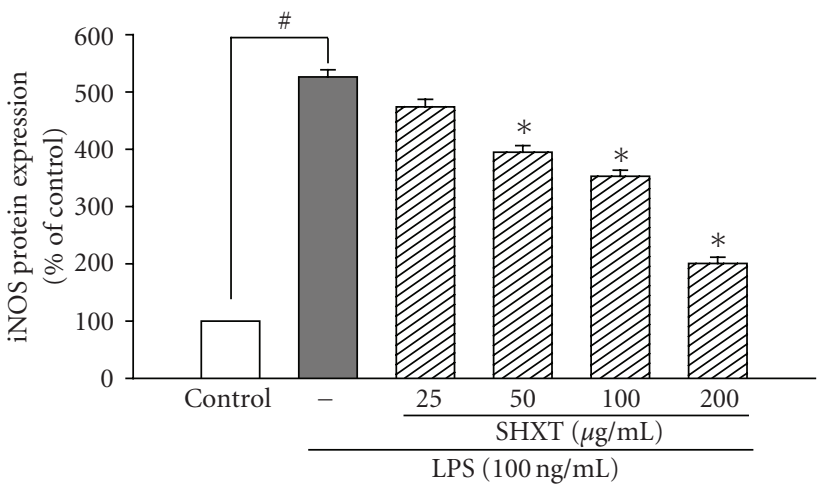

(a)
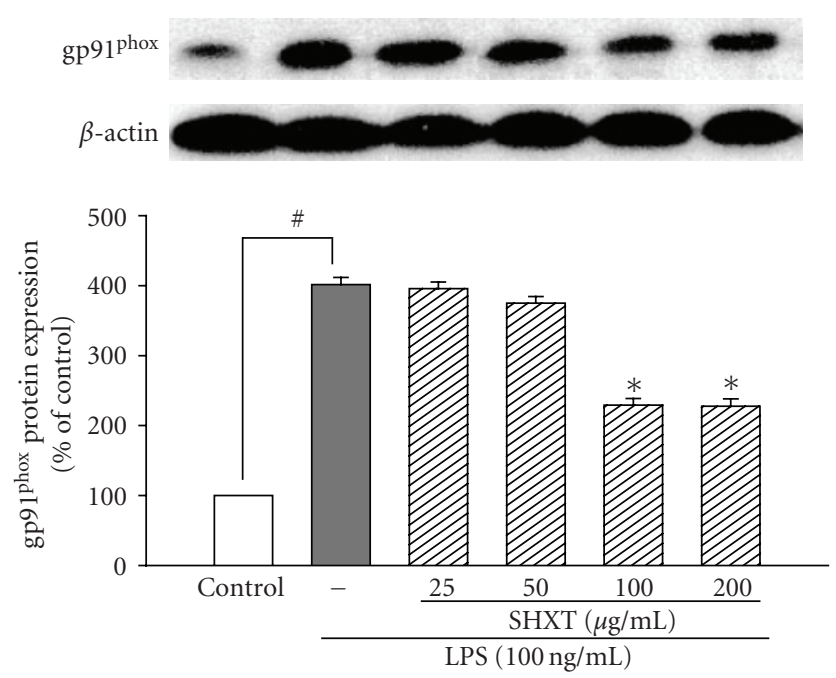

(c)
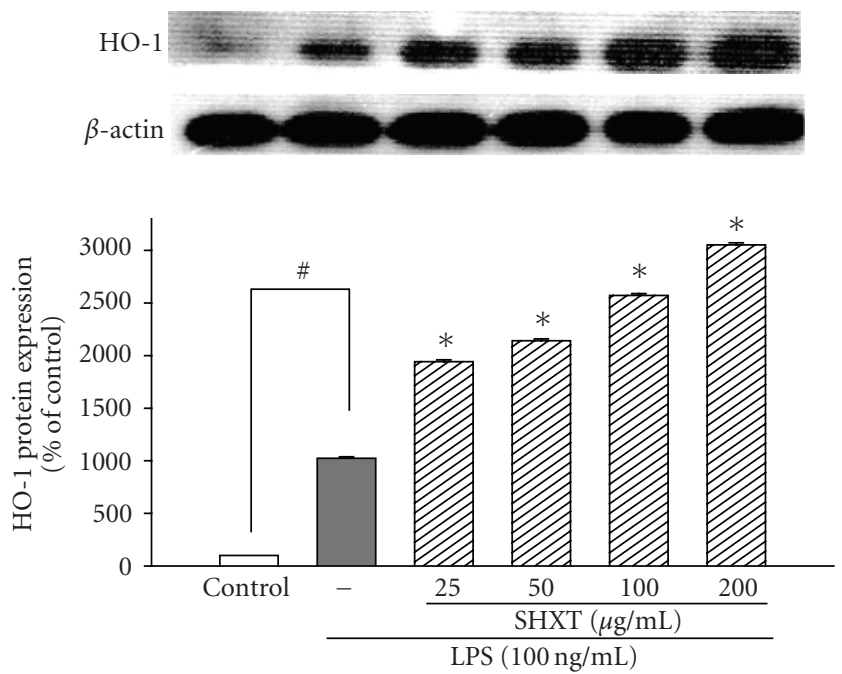

(d)

Figure 2: Effects of SHXT on expression of iNOS, COX-2, gp91phox and HO-1 in BV-2 cells treated with lipopolysaccharide (LPS, $100 \mathrm{ng} / \mathrm{mL}$ ) for $24 \mathrm{~h}$. Cultures were pretreated with SHXT for $30 \mathrm{~min}$ before the addition of LPS treatment. Bars represent the mean \pm SEM from six independent experiments. Densitometry analyses are presented as the relative ratio of protein/ $\beta$-actin protein, and are represented as percentages of the control group. ${ }^{\#} P<.05$ versus control, ${ }^{*} P<.05$ versus LPS only.

TABLE 1: Effects of SHXT $(25,50,100$ and $200 \mu \mathrm{g} / \mathrm{mL})$ on LPS-induced nitrite, PGE 2 , iROS, TNF- $\alpha$ and IL- $1 \beta$ production in BV-2 cells.

\begin{tabular}{lccccc}
\hline & Nitrite $(\mu \mathrm{M})$ & PGE $_{2}(\mathrm{pg} / \mathrm{mL})$ & iROS $(\%)$ & TNF- $\alpha(\mathrm{pg} / \mathrm{mL})$ & $\mathrm{IL}-1 \beta(\mathrm{pg} / \mathrm{mL})$ \\
\hline Control & $0.25 \pm 0.03$ & $14.45 \pm 1.53$ & 100 & $70.41 \pm 8.51$ & $10.51 \pm 3.57$ \\
LPS only & $3.76 \pm 0.20^{\#}$ & $41.83 \pm 2.53^{\#}$ & $201.52 \pm 9.52^{\#}$ & $704.61 \pm 30.53^{\#}$ & $68.51 \pm 5.65^{\#}$ \\
LPS + SHXT $25 \mu \mathrm{g} / \mathrm{mL}$ & $2.96 \pm 0.41$ & $27.39 \pm 2.14^{*}$ & $192.51 \pm 8.52$ & $650.25 \pm 20.56$ & $58.52 \pm 7.24$ \\
LPS + SHXT $50 \mu \mathrm{g} / \mathrm{mL}$ & $1.89 \pm 0.34^{*}$ & $22.52 \pm 1.95^{*}$ & $182.57 \pm 8.50$ & $552.53 \pm 10.51^{*}$ & $50.14 \pm 4.65^{*}$ \\
LPS + SHXT $100 \mu \mathrm{g} / \mathrm{mL}$ & $1.63 \pm 0.21^{*}$ & $21.62 \pm 1.52^{*}$ & $130.73 \pm 6.25^{*}$ & $430.56 \pm 12.86^{*}$ & $42.51 \pm 4.64^{*}$ \\
LPS + SHXT $200 \mu \mathrm{g} / \mathrm{mL}$ & $1.50 \pm 0.14^{*}$ & $14.68 \pm 1.35^{*}$ & $109.64 \pm 6.63^{*}$ & $263.50 \pm 15.58^{*}$ & $26.52 \pm 5.63^{*}$ \\
\hline
\end{tabular}

Values represent the mean \pm SEM from six independent experiments. ${ }^{*} P<.05$ versus control, ${ }^{*} P<.05$ versus LPS only. 


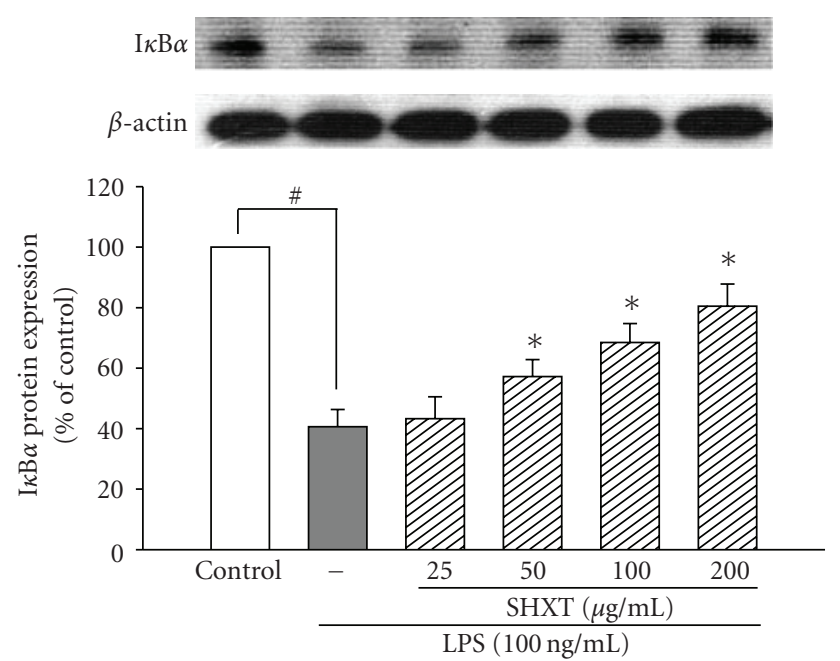

(a)

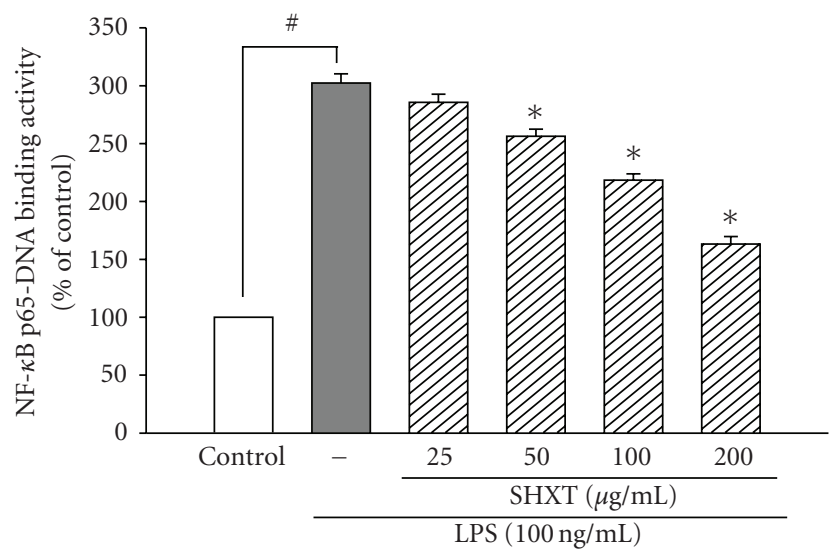

(b)

Figure 3: Effects of SHXT on the I $\kappa \mathrm{B} \alpha$ expression (a) and NF- $\kappa \mathrm{B}$ activation (b) in lipopolysaccharide (LPS, $100 \mathrm{ng} / \mathrm{mL}$ )-treated BV2 cells. Cultures were pretreated with SHXT for $30 \mathrm{~min}$ before the addition of LPS. Then the cells were collected at $1 \mathrm{~h}$ for NF- $\kappa \mathrm{B}$ activity assay and at $24 \mathrm{~h}$ for $\mathrm{I} \kappa \mathrm{B} \alpha$ protein analyses. Densitometry analyses are presented as the relative ratio of protein $/ \beta$-actin protein, and they are represented as percentages of the control group. Changes of NF- $\kappa \mathrm{Bp} 65$ translocation levels are represented as percentages of the control group. Bars represent the mean \pm SEM from six independent experiments. ${ }^{\#} P<.05$ versus control, ${ }^{*} P<.05$ versus LPS only.

production (Table 1). Furthermore, SHXT $(50-200 \mu \mathrm{g} / \mathrm{mL})$ concentration-dependently attenuated $\mathrm{I} \kappa \mathrm{B} \alpha$ degradation and NF- $\kappa$ Bp 65 translocation in LPS-treated BV-2 cells (Figure 3 ).

3.3. SHXT Inhibited Overproduction of TNF- $\alpha$ and $I L-1 \beta$ in LPS-Treated BV-2 Cells and Overexpression of $n N O S, C O X-$ 2 and $g$ p91 phox in SH-SY5Y Cells Co-Cultured with BV2 Cells. As shown in Table 1, LPS (100 ng/mL) caused a marked increase of TNF- $\alpha$ at $2 \mathrm{~h}$ and IL- $1 \beta$ at $24 \mathrm{~h}$ in BV2 cells. Results indicated SHXT concentration-dependently attenuated LPS-induced overproduction of TNF- $\alpha$ and IL$1 \beta$ from 25 to $200 \mu \mathrm{g} / \mathrm{mL}$ and 50 to $200 \mu \mathrm{g} / \mathrm{mL}$, respectively.

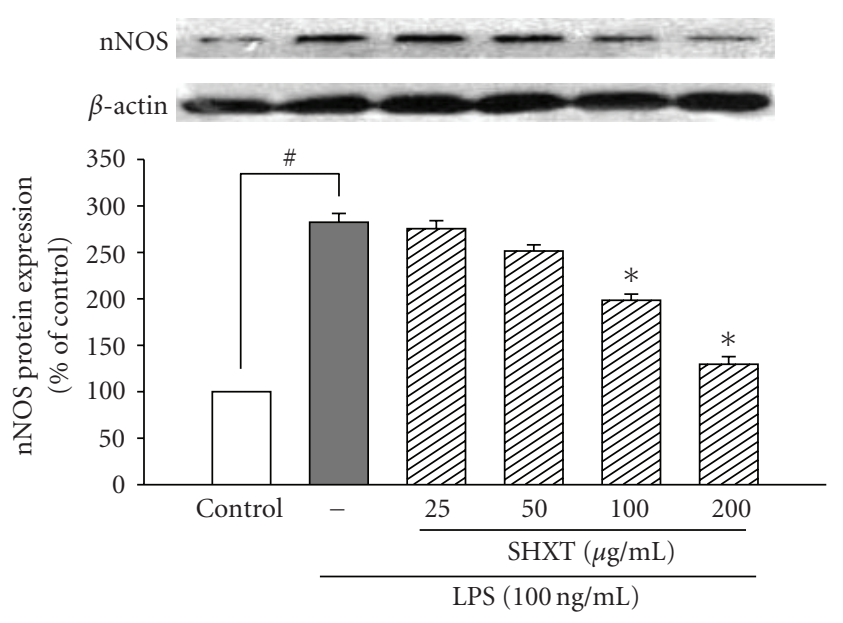

(a)

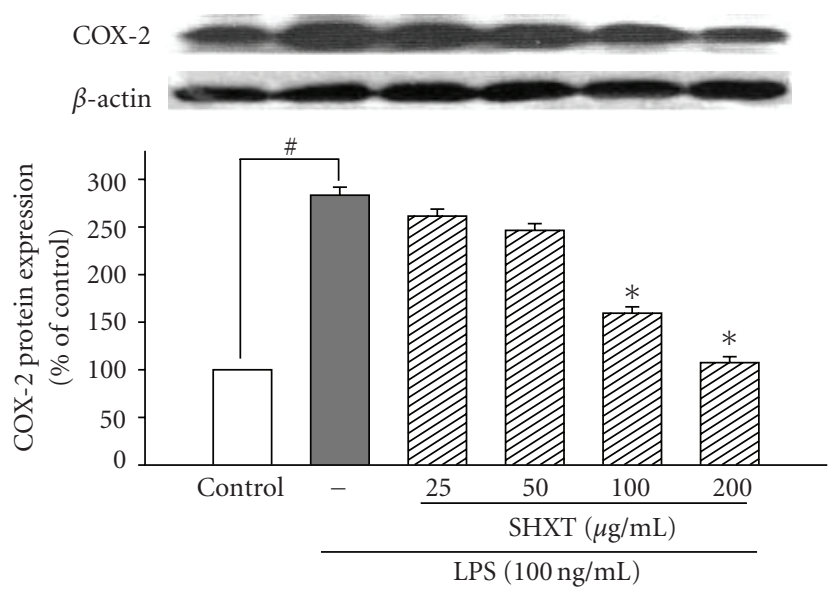

(b)

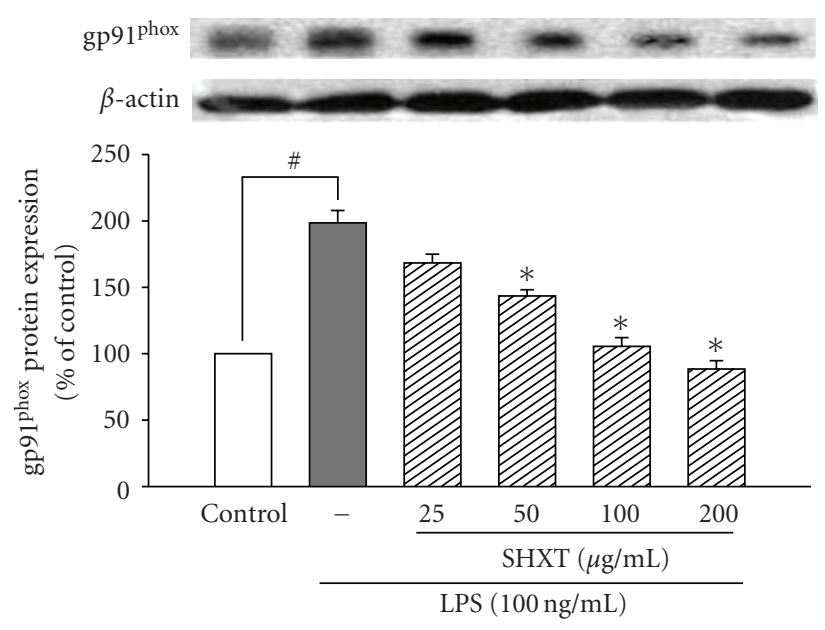

(c)

FIgURE 4: Inhibitory effects of SHXT on the expressions of nNOS (a), COX-2 (b) and gp91 ${ }^{\text {phox }}$ (c) in SH-SY5Y cells under coculture with lipopolysaccharide (LPS, $100 \mathrm{ng} / \mathrm{mL}$ )-treated BV-2 cells. Cultures were pretreated with SHXT for $30 \mathrm{~min}$ followed by LPS treatment for $24 \mathrm{~h}$. Densitometry analyses are presented as the relative ratio of protein $/ \beta$-actin protein, and are represented as percentages of the control group. Bars represent the mean \pm SEM from six independent experiments. ${ }^{\#} P<.05$ versus control, ${ }^{*} P<.05$ versus LPS only. 


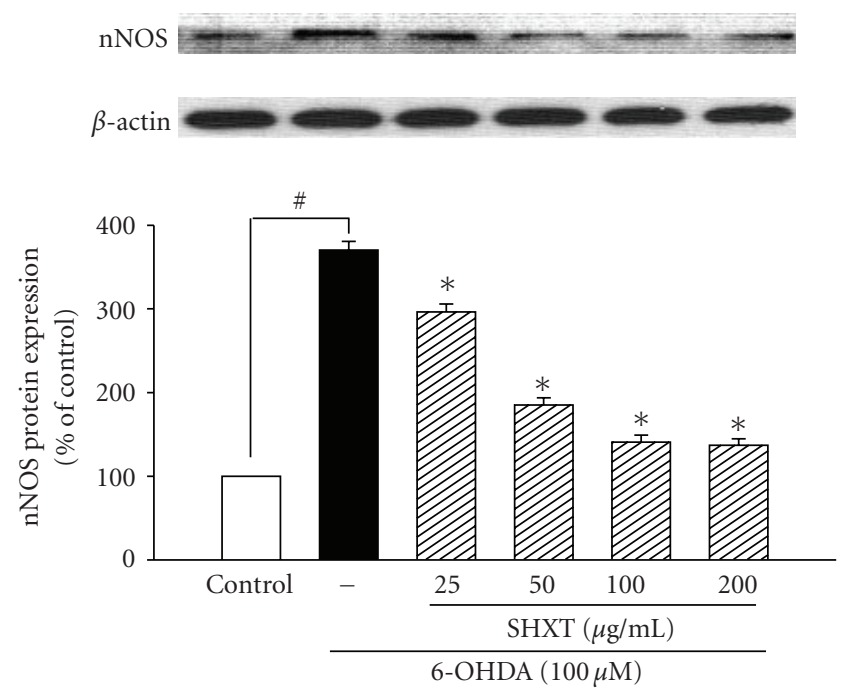

(a)

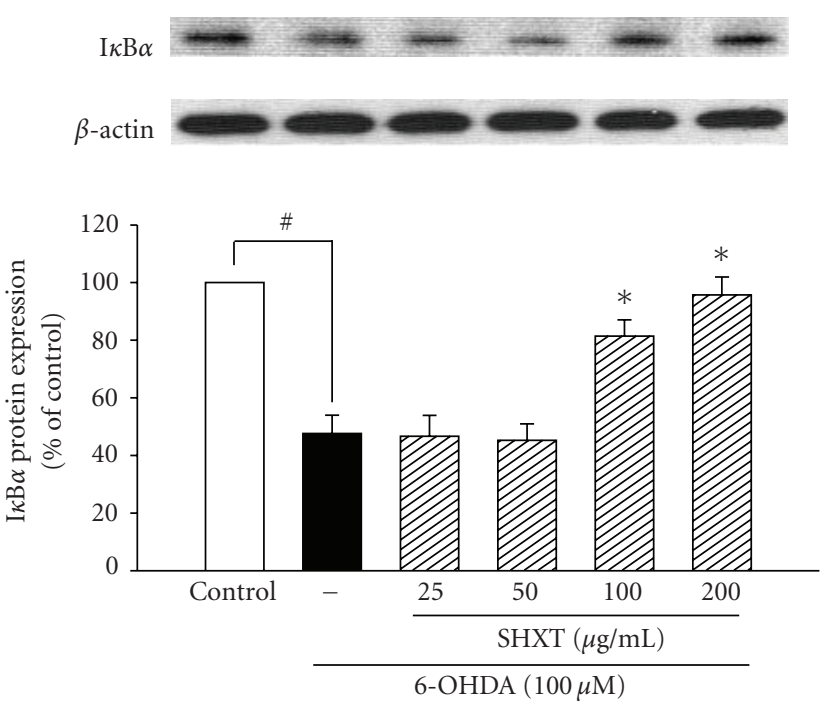

(c)

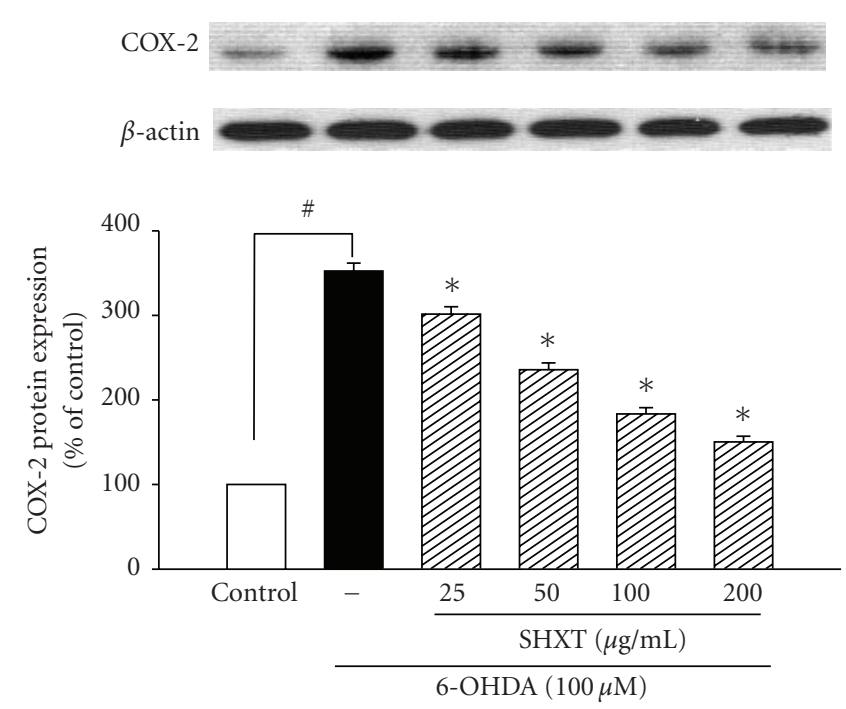

(b)

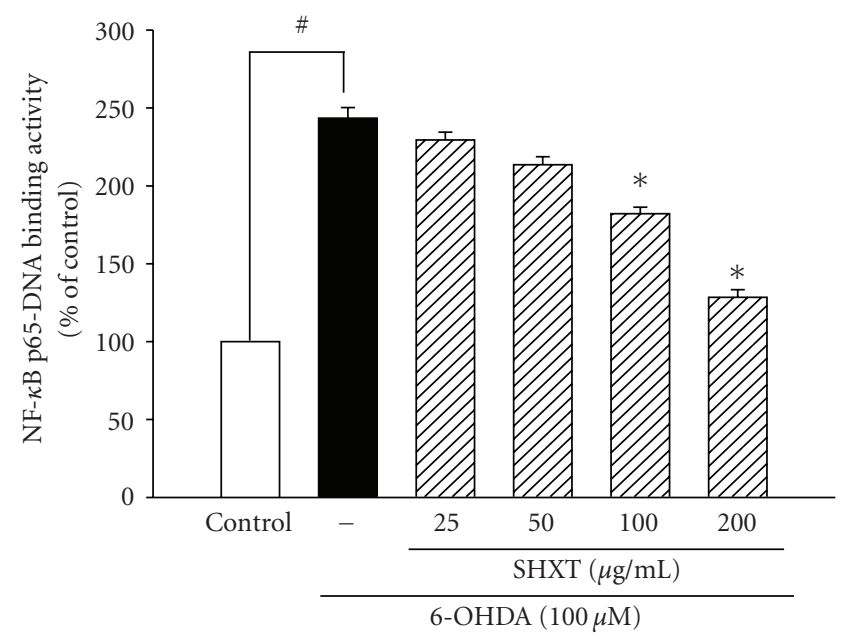

(d)

FIGURE 5: Inhibitory effects of SHXT on the expressions of nNOS (a), COX-2 (b), I $\kappa \mathrm{B} \alpha(\mathrm{c})$ and NF- $\kappa \mathrm{B}$ activation (d) on 6-hydroxydopamine (6-OHDA, $100 \mu \mathrm{M})$ treated SH-SY5Y cells. Cultures were pretreated with SHXT for 30 min before the addition of 6-OHDA. Then the cells were collected at $1.5 \mathrm{~h}$ for NF- $\kappa \mathrm{B}$ activity assay and at $24 \mathrm{~h}$ for $\mathrm{nNOS}, \mathrm{COX}-2$ and $\mathrm{I} \kappa \mathrm{B} \alpha$ protein analyses. Densitometry analyses are presented as the relative ratio of protein/ $\beta$-actin protein, and are represented as percentages of the control group. Changes of NF- $\kappa \mathrm{B}$ p65 translocation levels are represented as percentages of the control group. Bars represent the mean \pm SEM from six independent experiments. ${ }^{\#} P<.05$ versus control, ${ }^{*} P<.05$ versus 6 -OHDA only.

Under co-culture conditions, LPS exposure induced upregulation of nNOS, COX-2 and gp91 $1^{\text {phox }}$ of SH-SY5Y cells. However, SHXT $(50-200 \mu \mathrm{g} / \mathrm{mL})$ concentration-dependently attenuated LPS-activated BV-2 cell-induced overexpression of nNOS (Figure 4(a)), COX-2 (Figure 4(b)) and gp91phox (Figure 4(c)) on SH-SY5Y cells.

3.4. 6-OHDA-Induced Inflammatory Factors and Mitochondrial Membrane Potential Changes in SH-SY5Y Cells Were Attenuated by SHXT. SH-SY5Y cells treated with 6-OHDA
$(100 \mu \mathrm{M})$ for $24 \mathrm{~h}$ resulted in significant increases in expression of nNOS (Figure 5(a)) and COX-2 (Figure 5(b)), which were inhibited by SHXT $(25-200 \mu \mathrm{g} / \mathrm{mL})$. SHXT also inhibited 6-OHDA-induced $\mathrm{I} \kappa \mathrm{B} \alpha$ degradation (Figure 5(c)) and NF- $\kappa$ Bp65 translocation (Figure 5(d)) at a concentration of $100 \mu \mathrm{g} / \mathrm{mL}$ and $200 \mu \mathrm{g} / \mathrm{mL}$. SHXT $(25-200 \mu \mathrm{g} / \mathrm{mL})$ attenuated 6-OHDA-induced increases of gp91 ${ }^{\text {phox }}$ (Figure 6(a)) and iROS (Figure 6(b)). Furthermore, SHXT $(50-200 \mu \mathrm{g} / \mathrm{mL})$ significantly attenuated 6-OHDAinduced decrease in mitochondria membrane potential (Figure 6(c)). 


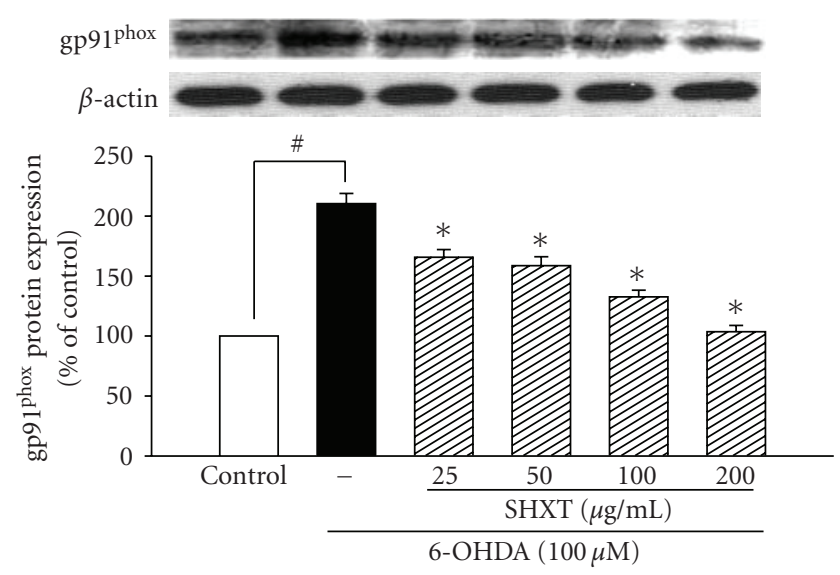

(a)

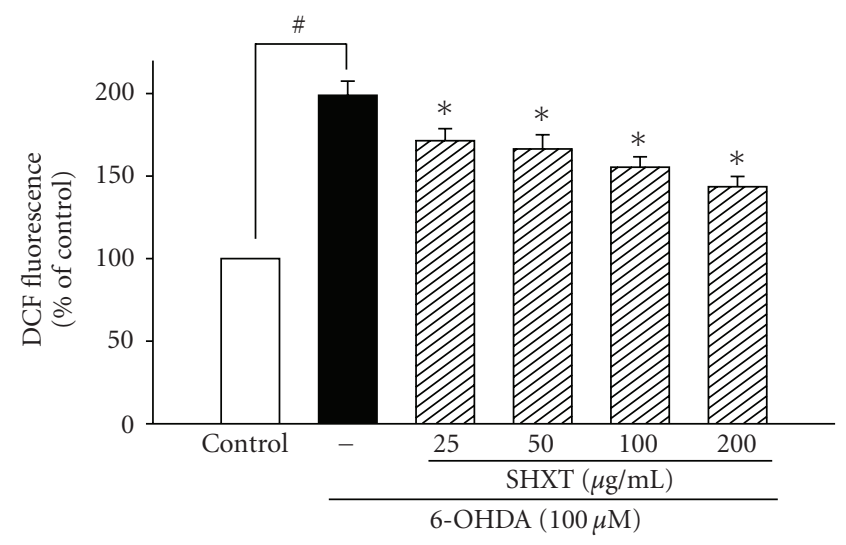

(b)

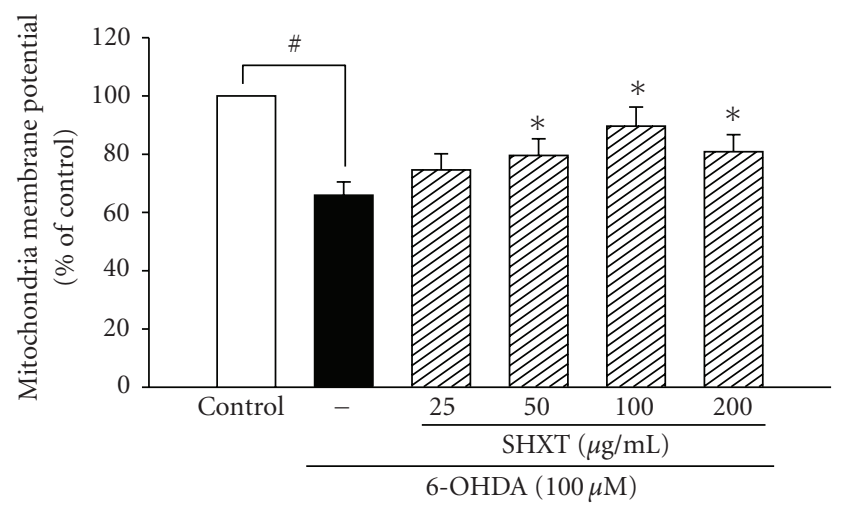

(c)

FIGURE 6: Effects of SHXT on 6-hydroxydopamine (6-OHDA, $100 \mu \mathrm{M}$ )-induced changes of gp91 $1^{\text {phox }}$ expression (a), iROS formation (b) and mitochondria membrane potential (c) in SH-SY5Y cells. The iROS was measured by using H2DCF-DA staining and mitochondrial membrane potential was measured by rhodamine 123. Densitometry analyses are presented as the relative ratio of protein $/ \beta$-actin protein, and are represented as percentages of the control group. Bars represent the mean \pm SEM from six independent experiments. ${ }^{\#} P<.05$ versus control group, ${ }^{*} P<.05$ versus 6-OHDA only.
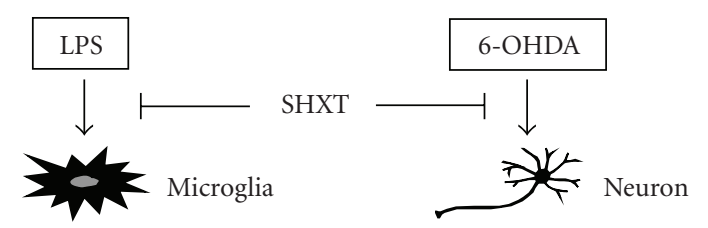
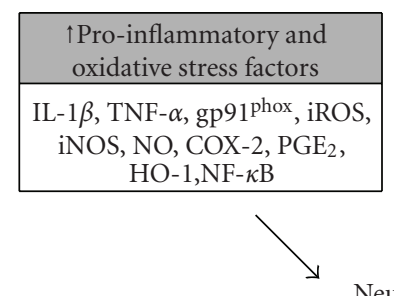

—: inhibition

FIgURE 7: Hypothetical protective mechanisms of SHXT on microglia-mediated and 6-OHDA-induced toxicity in neuronal cells.

\section{Discussion}

The present study demonstrated that SHXT could inhibit LPS-activated microglia- and neurotoxin 6-OHDA-induced neurotoxicity. The major findings showed that SHXT significantly reduced LPS-activated microglia- and 6-OHDAinduced neuronal cell death. In LPS-activated microglialike BV-2 cells, SHXT attenuated inflammatory cytokine TNF- $\alpha$ and IL- $1 \beta$, decreased the production of NO, $\mathrm{PGE}_{2}$ and iROS, downregulated overexpression of iNOS, COX2 and gp91 ${ }^{\text {phox }}$, decreased $\mathrm{I} \kappa \mathrm{B} \alpha$ degradation and NF$\kappa$ Bp65 translocation, and upregulated HO-1 expression. Moreover, SHXT downregulated overexpression of nNOS, COX-2, gp91 ${ }^{\text {phox }}$ on neuronal SH-SY5Y cells co-cultured with activated microglia BV-2 cells. In 6-OHDA-induced neurotoxicity, the protective effects of SHXT are mediated by downregulating nNOS, COX-2 and gp91phox, decreased iROS level, $\mathrm{I} \kappa \mathrm{B} \alpha$ degradation and NF- $\kappa \mathrm{Bp} 65$ translocation and increased mitochondria membrane potential of $\mathrm{SH}-$ SY5Y cells (Figure 7).

Microglial-mediated neurotoxicity has been implicated in numerous neurodegenerative diseases [29]. Activated microglia increase oxidative stress [36] and inflammatory mediators [37]. Pro-inflammatory cytokines TNF- $\alpha$ and IL$1 \beta$ are thought to play a major role in inducing neuronal death [38]. In this study, SHXT significantly attenuated LPSinduced increase of pro-inflammatory cytokines (TNF- $\alpha$ and IL-1 $\beta$ ) on BV-2 cells. Moreover, pro-inflammatory cytokines can induce iNOS expression and subsequently induce large amounts of NO production in activated microglia [7]. NO, together with iNOS and nNOS, is known to be involved in the pathogenesis of $\operatorname{PD}[39,40]$. Excessive accumulation of NO has long been known to be toxic to neurons [41]. Oxygen free radicals such as superoxide can react with NO to form much more deadly intermediates such as peroxynitrite [42]. The current results indicated that SHXT not only reduced LPS-activated microglia-induced increase of iNOS and NO, but also decreased the overexpression of nNOS in microglia-stimulated neuronal SH-SY5Y cells. SHXT also 
attenuated the overexpression of nNOS induced by 6-OHDA in SH-SY5Y cells. COX-2 is believed to be a critical enzyme in the inflammatory response and has been implicated in neuronal survival and death [43]. Cytokines (particularly TNF- $\alpha$ ) activate COX-2 enzymes, and inhibition of COX-2 has been shown to provide neuroprotection [44]. Our results showed that SHXT not only decreased TNF- $\alpha$ production but also attenuated COX-2 expression and $\mathrm{PGE}_{2}$ production on LPS-treated microglia BV-2 cells. SHXT also inhibited overexpression of COX-2 on activated microglia-treated or 6-OHDA-treated neuronal SH-SY5Y cells. It is well known that $\mathrm{HO}-1$ can inhibit iNOS expression and NO production in activated macrophages via inactivation of NF- $\kappa \mathrm{B}[45,46]$. Our results showed that SHXT inhibited LPS-induced iNOS expression, NO production, $\mathrm{I} \kappa \mathrm{B} \alpha$ degradation and NF- $\kappa \mathrm{B}$ p65 translocation. SHXT also enhanced HO-1 expression.

Phagocyte NADPH oxidase (PHOX) is a major source of superoxide and the catalytic center of this oxidase is the membrane-integrated protein $\mathrm{gp} 91^{\text {phox }}[47,48]$. NADPH oxidase is deeply involved with microglia-induced neurotoxicity as a result of either generating extracellular ROS or by increasing microglia intracellular ROS production, which activates the generation of pro-inflammatory mediators and subsequently induces damages to neurons [1]. Microglia are critical to NADPH oxidase-mediated neurotoxicity in LPSinduced inflammation-mediated neurodegeneration [49]. Our study showed that SHXT decreased gp91 phox overexpression and iROS levels on LPS-activated BV-2 cells. SHXT also downregulated gp91 ${ }^{\text {phox }}$ overexpression on SH-SY5Y cells co-cultured with LPS-activated microglia BV-2 cells. Additionally, NADPH oxidase-generated ROS are involved in the signaling event leading to COX-2 expression and $\mathrm{PGE}_{2}$ production in microglia treated with LPS [50]. The present results indicated SHXT inhibited gp $91^{\text {phox }}$, iROS, COX-2 and $\mathrm{PGE}_{2}$. Therefore, the protective effects of SHXT on LPSactivated microglia-induced neuronal cell damage might be due to its anti-inflammatory and anti-oxidative effects.

It has been reported that the auto-oxidation of dopamine to 6-OHDA generates ROS and reactive quinones [31, 32], which subsequently induces lipid peroxidation, damages mitochondrial membrane and results eventually in the collapse of mitochondrial membrane potential, leading to cell death [51]. The present results indicated that SHXT decreased gp91 ${ }^{\text {phox }}$ overexpression and iROS levels in SHSY5Y cells exposed to 6-OHDA. SHXT also attenuated the decrease of mitochondrial membrane potential and cell death induced by 6-OHDA. Furthermore, SHXT also inhibited 6-OHDA-induced increases of nNOS, COX-2, I $\kappa \mathrm{B} \alpha$ degradation and NF- $\kappa$ Bp 65 translocation. Therefore, the prevention of SHXT on 6-OHDA-induced neuronal cell damage might be partly mediated via decreasing production of iROS, increasing mitochondrial membrane potential and attenuating overexpression of inflammatory protein.

In conclusion, this study suggests that SHXT can effectively attenuate LPS-activated microglia- and neurotoxin 6OHDA-induced neurotoxicity. Considering the importance of inflammation and ROS in neurodegeneration, SHXT might have a protective potential in the microglia-mediated or oxidative stress-related neurodegenerative disorders.

\section{Supplementary Data}

Supplementary data are available at $e C A M$ online.

\section{Funding}

National Science Council, Taiwan (NSC-96-2320-B-037039-MY3).

\section{Acknowledgment}

The authors thank Belinda Wilson for her editorial assistance.

\section{References}

[1] P. S. Whitton, "Inflammation as a causative factor in the aetiology of Parkinson's disease," British Journal of Pharmacology, vol. 150, no. 8, pp. 963-976, 2007.

[2] R. von Bernhardi, "Glial cell dysregulation: a new perspective on Alzheimer disease," Neurotoxicity Research, vol. 12, no. 4, pp. 215-232, 2007.

[3] R. A. Adams, C. Schachtrup, D. Davalos, I. Tsigelny, and K. Akassoglou, "Fibrinogen signal transduction as a mediator and therapeutic target in inflammation: Lessons from multiple sclerosis," Current Medicinal Chemistry, vol. 14, no. 27, pp. 2925-2936, 2007.

[4] S. U. Kim and J. De Vellis, "Microglia in health and disease," Journal of Neuroscience Research, vol. 81, no. 3, pp. 302-313, 2005.

[5] H.-M. Gao, J. Jiang, B. Wilson, W. Zhang, J.-S. Hong, and B. Liu, "Microglial activation-mediated delayed and progressive degeneration of rat nigral dopaminergic neurons: relevance to Parkinson's disease," Journal of Neurochemistry, vol. 81, no. 6, pp. 1285-1297, 2002.

[6] H.-M. Gao, J.-S. Hong, W. Zhang, and B. Liu, "Synergistic dopaminergic neurotoxicity of the pesticide rotenone and inflammogen lipopolysaccharide: relevance to the etiology of Parkinson's disease," Journal of Neuroscience, vol. 23, no. 4, pp. 1228-1236, 2003.

[7] M. M. Iravani, C. C. M. Leung, M. Sadeghian, C. O. Haddon, S. Rose, and P. Jenner, "The acute and the long-term effects of nigral lipopolysaccharide administration on dopaminergic dysfunction and glial cell activation," European Journal of Neuroscience, vol. 22, no. 2, pp. 317-330, 2005.

[8] J. E. Merrill, "Tumor necrosis factor alpha, interleukin 1 and related cytokines in brain development: normal and pathological," Developmental Neuroscience, vol. 14, no. 1, pp. $1-10,1992$.

[9] S. Mandel, E. Grünblatt, P. Riederer, M. Gerlach, Y. Levites, and M. B. H. Youdim, "Neuroprotective strategies in Parkinson's disease: an update on progress," CNS Drugs, vol. 17, no. 10, pp. 729-762, 2003.

[10] Y.-C. Lo, Y. Liu, Y.-C. Lin, Y.-T. Shih, C.-M. Liu, and L. T. Burka, "Neuronal effects of 4-t-butylcatechol: a model for catechol-containing antioxidants," Toxicology and Applied Pharmacology, vol. 228, no. 2, pp. 247-255, 2008.

[11] Y. C. Lin, H. W. Uang, R. J. Lin, I. J. Chen, and Y. C. Lo, "Neuroprotective effects of glyceryl nonivamide against microglialike cells and 6-hydroxydopamine-induced neurotoxicity in SH-SY5Y human dopaminergic neuroblastoma cells," Journal of Pharmacology and Experimental Therapeutics, vol. 323, pp. 877-887, 2007. 
[12] Y. Liu, L. Qin, G. Li et al., "Dextromethorphan protects dopaminergic neurons against inflammation-mediated degeneration through inhibition of microglial activation," Journal of Pharmacology and Experimental Therapeutics, vol. 305, no. 1, pp. 212-218, 2003.

[13] D. C. Wu, V. Jackson-Lewis, M. Vila et al., "Blockade of microglial activation is neuroprotective in the 1-methyl-4phenyl-1,2,3,6-tetrahydropyridine mouse model of Parkinson disease," Journal of Neuroscience, vol. 22, no. 5, pp. 1763-1771, 2002.

[14] K. Suk, H. Lee, S. S. Kang, G. J. Cho, and W. S. Choi, "Flavonoid baicalein attenuates activation-induced cell death of brain microglia," Journal of Pharmacology and Experimental Therapeutics, vol. 305, no. 2, pp. 638-645, 2003.

[15] L. W. Chen, Y. Q. Wang, L. C. Wei, M. Shi, and Y. S. Chan, "Chinese herbs and herbal extracts for neuroprotection of dopaminergic neurons and potential therapeutic treatment of Parkinson's disease," CNS \& Neurological Disorders Drug Targets, vol. 6, pp. 273-281, 2007.

[16] M. Shimazawa, S. Chikamatsu, N. Morimoto, S. Mishima, H. Nagai, and H. Hara, "Neuroprotection by Brazilian green propolis against in vitro and in vivo ischemic neuronal damage," Evidence-Based Complementary and Alternative Medicine, vol. 2, pp. 201-207, 2005.

[17] Y. S. Ho, M. S. Yu, C. S. Lai, K. F. So, W. H. Yuen, and R. C. Chang, "Characterizing the neuroprotective effects of alkaline extract of Lycium barbarum on beta-amyloid peptide neurotoxicity," Brain Research, vol. 1158, pp. 123-134, 2007.

[18] F.-Q. Li, T. Wang, Z. Pei, B. Liu, and J.-S. Hong, "Inhibition of microglial activation by the herbal flavonoid baicalein attenuates inflammation-mediated degeneration of dopaminergic neurons," Journal of Neural Transmission, vol. 112, no. 3, pp. 331-347, 2005.

[19] H. Lee, Y. O. Kim, H. Kim et al., "Flavonoid wogonin from medicinal herb is neuroprotective by inhibiting inflammatory activation of microglia," The FASEBJ Journal, vol. 17, pp. 1943-1944, 2003

[20] W.-C. Lin and T.-W. Tan, "The role of gastric muscle relaxation in cytoprotection induced by San-huang-xie-xintang in rats," Journal of Ethnopharmacology, vol. 44, no. 3, pp. 171-179, 1994.

[21] Y. T. Shih, D. C. Wu, C. M. Liu, Y. C. Yang, I. J. Chen, and Y. C. Lo, "San-Huang-Xie-Xin-Tang inhibits Helicobacter pyloriinduced inflammation in human gastric epithelial AGS cells," Journal of Ethnopharmacology, vol. 112, pp. 537-544, 2007.

[22] Y.-C. Lo, P.-L. Tsai, Y.-B. Huang et al., "San-Huang-Xie-XinTang reduces lipopolysaccharides-induced hypotension and inflammatory mediators," Journal of Ethnopharmacology, vol. 96, no. 1-2, pp. 99-106, 2005.

[23] Y. C. Lo, Y. L. Lin, K. L. Yu et al., "San-Huang-Xie-Xin-Tang attenuates inflammatory responses in lipopolysaccharideexposed rat lungs," Journal of Ethnopharmacology, vol. 101, no. 1-3, pp. 68-74, 2005.

[24] H. J. Heo, D.-O. Kim, S. J. Choi, D. H. Shin, and C. Y. Lee, "Potent inhibitory effect of flavonoids in Scutellaria baicalensis on amyloid $\beta$ protein-induced neurotoxicity," Journal of Agricultural and Food Chemistry, vol. 52, no. 13, pp. 41284132, 2004

[25] Q. F. Ge, X. Hu, Z. Q. Ma, J. R. Liu, W. P. Zhang, Z. Chen et al., "Baicalin attenuates oxygen-glucose deprivationinduced injury via inhibiting NMDA receptor-mediated 5lipoxygenase activation in rat cortical neurons," Pharmacological Research, vol. 55, pp. 148-157, 2007.
[26] J.-W. Gu, H. Hasuo, M. Takeya, and T. Akasu, "Effects of emodin on synaptic transmission in rat hippocampal CA1 pyramidal neurons in vitro," Neuropharmacology, vol. 49, no. 1, pp. 103-111, 2005.

[27] H. An, H. Xu, Y. Yu et al., "Up-regulation of TLR9 gene expression by LPS in mouse macrophages via activation of NFkappaB, ERK and p38 MAPK signal pathways," Immunology Letters, vol. 81, pp. 165-169, 2002.

[28] L. Qian, M. L. Block, S.-J. Wei et al., "Interleukin-10 protects lipopolysaccharide-induced neurotoxicity in primary midbrain cultures by inhibiting the function of NADPH oxidase," Journal of Pharmacology and Experimental Therapeutics, vol. 319, no. 1, pp. 44-52, 2006.

[29] M. L. Block, L. Zecca, and J.-S. Hong, "Microglia-mediated neurotoxicity: uncovering the molecular mechanisms," Nature Reviews Neuroscience, vol. 8, no. 1, pp. 57-69, 2007.

[30] M. L. Block and J.-S. Hong, "Microglia and inflammationmediated neurodegeneration: multiple triggers with a common mechanism," Progress in Neurobiology, vol. 76, no. 2, pp. 77-98, 2005.

[31] D. Blum, S. Torch, N. Lambeng et al., "Molecular pathways involved in the neurotoxicity of 6-OHDA, dopamine and MPTP: contribution to the apoptotic theory in Parkinson's disease," Progress in Neurobiology, vol. 65, no. 2, pp. 135-172, 2001.

[32] K. Hanrott, L. Gudmunsen, M. J. O’Neill, and S. Wonnacott, "6-hydroxydopamine-induced apoptosis is mediated via extracellular auto-oxidation and caspase 3-dependent activation of protein kinase C $\delta$," Journal of Biological Chemistry, vol. 281, no. 9, pp. 5373-5382, 2006.

[33] A. M. Benotmane, M. F. Hoylaerts, D. Collen, and A. Belayew, "Nonisotopic quantitative analysis of protein-DNA interactions at equilibrium," Analytical Biochemistry, vol. 250, no. 2, pp. 181-185, 1997.

[34] G. Baumgarten, P. Knuefermann, N. Nozaki, N. Sivasubramanian, D. L. Mann, and J. G. Vallejo, "In vivo expression of proinflammatory mediators in the adult heart after endotoxin administration: the role of toll-like receptor-4," The Journal of Infectious Diseases, vol. 183, pp. 1617-1624, 2001.

[35] Z. Shen, J. Peedikayil, G. K. Olson, P. D. Siebert, and Y. Fang, "Multiple transcription factor profiling by enzymelinked immunoassay," BioTechniques, vol. 32, no. 5, pp. 11681177, 2002.

[36] D. W. Dickson, S. C. Lee, L. A. Mattiace, S. H. Yen, and C. Brosnan, "Microglia and cytokines in neurological disease, with special reference to AIDS and Alzheimer's disease," Glia, vol. 7, no. 1, pp. 75-83, 1993.

[37] C. C. Chao, S. Hu, and P. K. Peterson, "Glia, cytokines, and neurotoxicity," Critical Reviews in Neurobiology, vol. 9, no. 23, pp. 189-205, 1995.

[38] F. Aloisi, "Immune function of microglia," Glia, vol. 36, no. 2, pp. 165-179, 2001.

[39] S. Przedborski, V. Jackson-Lewis, R. Yokoyama, T. Shibata, V. L. Dawson, and T. M. Dawson, "Role of neuronal nitric oxide in 1-methyl-4-phenyl-1,2,3,6-tetrahydropyridine (MPTP)-induced dopaminergic neurotoxicity," Proceedings of the National Academy of Sciences of the United States of America, vol. 93, no. 10, pp. 4565-4571, 1996.

[40] P. Klivenyi, O. A. Andreassen, R. J. Ferrante, E. Lancelot, D. Reif, and M. F. Beal, "Inhibition of neuronal nitric oxide synthase protects against MPTP toxicity," NeuroReport, vol. 11, no. 6, pp. 1265-1268, 2000.

[41] Z. Xie, M. Wei, T. E. Morgan et al., "Peroxynitrite mediates neurotoxicity of amyloid $\beta$-peptide $1-42$ - and 
lipopolysaccharide-activated microglia," Journal of Neuroscience, vol. 22, no. 9, pp. 3484-3492, 2002.

[42] A. G. Estévez and J. Jordán, "Nitric oxide and superoxide, a deadly cocktail," Annals of the New York Academy of Sciences, vol. 962, pp. 207-211, 2002.

[43] R. Vijitruth, M. Liu, D.-Y. Choi, X. V. Nguyen, R. L. Hunter, and G. Bing, "Cyclooxygenase-2 mediates microglial activation and secondary dopaminergic cell death in the mouse MPTP model of Parkinson's disease," Journal of Neuroinflammation, vol. 3, Article ID 6, 2006.

[44] P. Teismann and B. Ferger, "Inhibition of the cyclooxygenase isoenzymes COX-1 and COX-2 provide neuroprotection in the MPTP-mouse model of Parkinson's disease," Synapse, vol. 39, no. 2, pp. 167-174, 2001.

[45] G.-S. Oh, H.-O. Pae, B.-S. Lee et al., "Hydrogen sulfide inhibits nitric oxide production and nuclear factor- $\kappa \mathrm{B}$ via heme oxygenase-1 expression in RAW264.7 macrophages stimulated with lipopolysaccharide," Free Radical Biology and Medicine, vol. 41, no. 1, pp. 106-119, 2006.

[46] K. M. Kim, H.-O. Pae, M. Zhung et al., "Involvement of antiinflammatory heme oxygenase- 1 in the inhibitory effect of curcumin on the expression of pro-inflammatory inducible nitric oxide synthase in RAW264.7 macrophages," Biomedicine and Pharmacotherapy, vol. 62, no. 9, pp. 630-636, 2008.

[47] R. Takeya, N. Ueno, and H. Sumimoto, "Regulation of superoxide-producing NADPH oxidases in nonphagocytic cells," Methods in Enzymology, vol. 406, Article ID 34, pp. 456468, 2006.

[48] H. Sumimoto, K. Miyano, and R. Takeya, "Molecular composition and regulation of the Nox family NAD $(\mathrm{P}) \mathrm{H}$ oxidases," Biochemical and Biophysical Research Communications, vol. 338, no. 1, pp. 677-686, 2005.

[49] L. Qin, Y. Liu, T. Wang et al., "NADPH oxidase mediates lipopolysaccharide-induced neurotoxicity and proinflammatory gene expression in activated microglia," Journal of Biological Chemistry, vol. 279, no. 2, pp. 1415-1421, 2004.

[50] T. Wang, L. Qin, B. Liu et al., "Role of reactive oxygen species in LPS-induced production of prostaglandin E2 in microglia," Journal of Neurochemistry, vol. 88, no. 4, pp. 939-947, 2004.

[51] S. Guo, E. Bezard, and B. Zhao, "Protective effect of green tea polyphenols on the SH-SY5Y cells against 6-OHDA induced apoptosis through ROS-NO pathway," Free Radical Biology and Medicine, vol. 39, no. 5, pp. 682-695, 2005. 


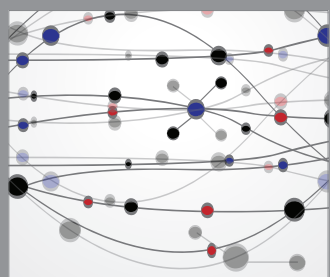

The Scientific World Journal
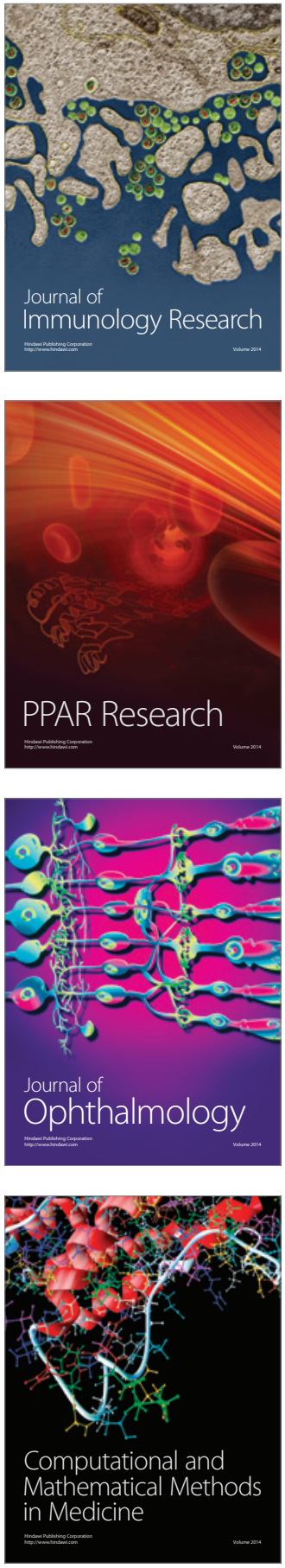

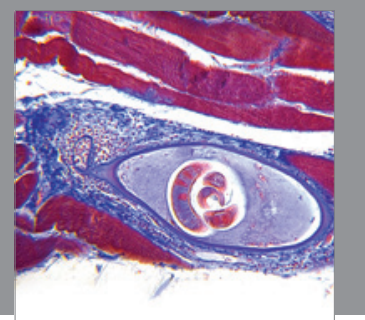

Gastroenterology

Research and Practice
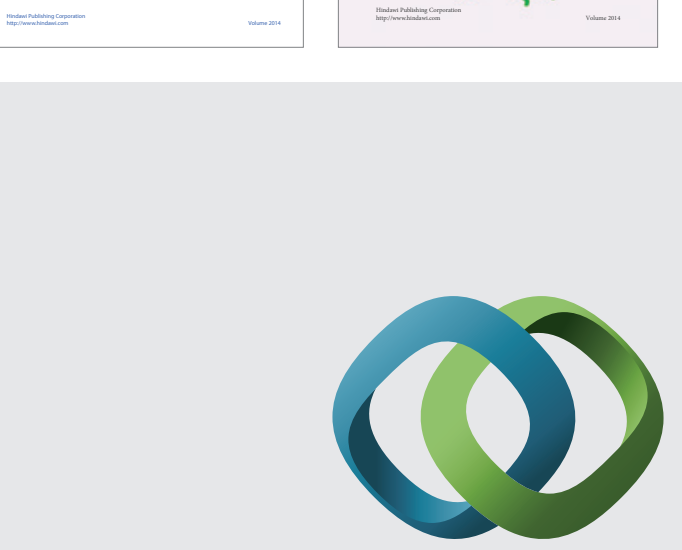

\section{Hindawi}

Submit your manuscripts at

http://www.hindawi.com
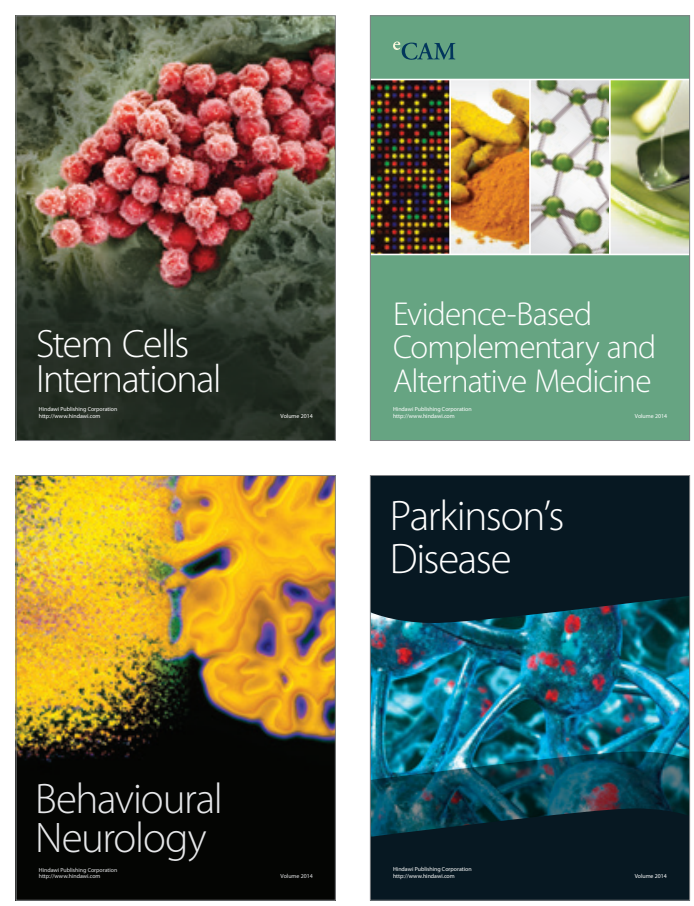

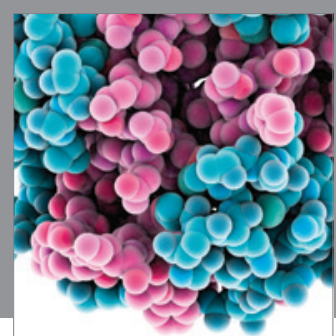

Journal of
Diabetes Research

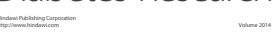

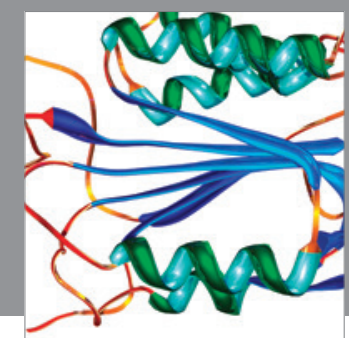

Disease Markers
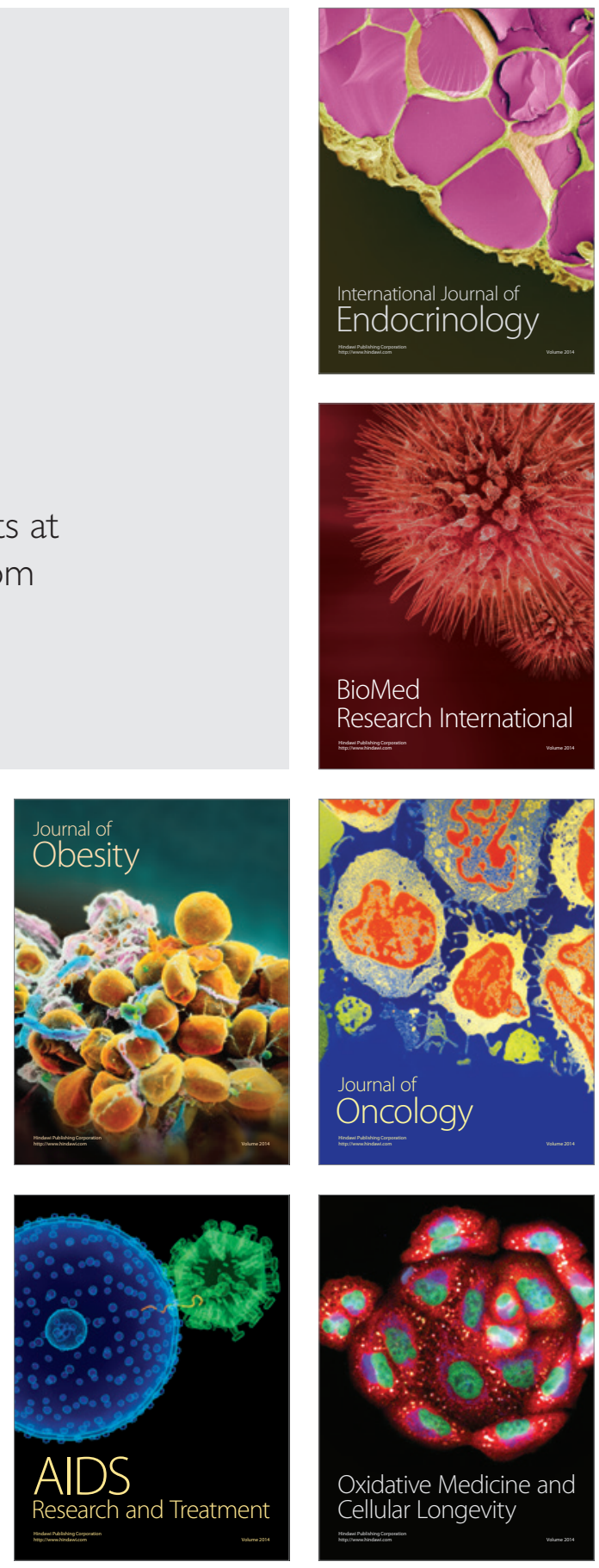